\section{'Cell or Not to Cell' that is the Question: For Intervertebral Disc Regeneration?}

\author{
Thorpe $\mathrm{AA}^{1}$, Sammon $\mathrm{C}^{2}$ and Le Maitre $\mathrm{CL}^{1 *}$ \\ ${ }^{1}$ Head of Musculoskeletal Research Group, Biomolecular Sciences
} Research Centre, Sheffield Hallam University, Sheffield, UK

${ }^{2}$ Materials and Engineering Research Institute, Sheffield Hallam University, Sheffield, UK

\begin{abstract}
Low back pain, strongly associated with intervertebral disc degeneration, is one of the most prevalent health problems in the western world today. Current treatments have been directed toward alleviating patient symptoms but have been shown to accelerate degenerative changes in adjacent discs. New approaches in tissue engineering have provided a variety of treatment options including the delivery of regenerative cells, either alone or together with hydrogel scaffolds in order to restore/maintain disc biomechanics whilst simultaneously regenerating the matrix. This review paper discusses the use of cellular and acellular therapeutic strategies for IVD degeneration with an emphasis on the importance of tailoring the treatment strategy with stage of degeneration, thus offering insight into the future clinical options for IVD regeneration.

Keywords: Biomaterials; Intervertebral disc; Regeneration; Stem Cells
\end{abstract}

\section{Anatomy of the Intervertebral Disc}

The Human Intervertebral Disc (IVD) is a fibrocartilagenous structure positioned between each connecting vertebra of the spinal column. Mechanically, the IVD transmits load, arising from body weight and muscle activity, and permits a range of spinal movement including bending, flexion and torsion [1]. The normal IVD is composed of three morphologically distinct regions: the Cartilaginous End Plates (CEP), the highly organised Annulus Fibrosus (AF) and the central gelatinous Nucleus Pulposus (NP), which operate collectively to mechanically transfer loads and disperse energy evenly throughout the spine. The CEP is a layer of hyaline cartilage which separates the AF and NP from the adjacent vertebral body and facilitates diffusion of nutrients and oxygen to the avascular internal structures of the IVD $[2,3]$. The AF can be further subdivided

*Corresponding author: Christine Le Maitre, Head of Musculoskeletal Research Group, Bimolecular Sciences Research Centre, Sheffield Hallam University, Sheffield, S11WB, UK, Tel: +44 01142256163; E-mail: c.lemaitre@shu.ac.uk

Citation: Thorpe AA, Sammon C, Le Maitre CL (2015) 'Cell or Not to Cell' that is the Question: For Intervertebral Disc Regeneration? J Stem Cell Res Dev Ther 2: 003.

Received: February 13, 2015; Accepted: March 23, 2015; Published: March 06, 2015 into the outer and the inner AF. The outer AF contains large amounts of fibrous collagen type I orientated into lamellae, providing resistance to tensile forces from bending and twisting of the vertebral column [4]. The inner AF is a transition zone between the randomly organised, hydrated NP and the highly organised, fibrous outer AF, with characteristics of both tissue types observed in this region. The NP has a gelatinous matrix composed of randomly arranged collagen type II fibres, radially arranged elastin fibres and small amounts of collagen types VI, IX and XI, all of which are embedded in a highly hydrated matrix rich in proteoglycans (mainly aggrecan) [5]. The hydrated proteoglycans provide viscoelasticity and resistance to compression whilst the collagen crosslinks confer tensile strength [6].

\section{Cell Types Present in the Normal IVD}

The cells which reside in the NP and AF are morphologically and phenotypically distinct. At maturity the AF contains elongated fibroblast like cells at a cell density of approximately $9 \times 10^{6} \mathrm{cells} / \mathrm{cm}^{3}$ [7]. At birth NP cells display large $(25-85 \mu \mathrm{m})$ vacuolated morphology with distinct resemblance to the embryonic notochordal cells from which they are assumed to originate [8-10]. During maturation the population of large vacuolated cells within the NP decreases and becomes replaced by smaller, round and non-vacuolated chondrocyte like cells at a cell density of approximately $4 \times 10^{6}$ cells/ $\mathrm{cm}^{3}[7,10,11]$. The origin of these smaller chondrocyte like cells in the NP is currently an unresolved area of IVD research with controversy as to whether the chondrocyte like cells migrate from surrounding tissues or differentiate from the notochordal cells $[12,13]$. Furthermore a definitive phenotypic maker of NP cells is yet to be characterised, thus the origin and profile of these cells remains a significant challenge for cell based regenerative strategies [14-18].

\section{Degeneration of the IVD}

Degeneration of the IVD is characterised by progressive changes in the Extracellular Matrix (ECM) due to altered cell metabolism, matrix synthesis and an increase in degradation of normal matrix components $[19,20]$. As IVD degeneration advances collagen type II in the NP is gradually replaced by the more fibrous collagen type I [7]. The overall proteoglycan composition of the NP is reduced and altered by decreased synthesis of aggrecan and increased synthesis of versican, decorin and biglycan, thus resulting in reduced water bibing capacity and a consequential decreased hydration of the extracellular matrix within the NP $[21,22]$. Concurrently matrix degradation is accelerated by the upregulation of MMPs (Matrix Metallinoproteinases) and ADAMTS (A Disintegrin And Metalloproteinase With Thrombospondin Motifs) [23,24]. Compositional changes in the matrix during IVD degeneration is also accompanied by cellular changes with increased apoptosis $[25,26]$ and senescence $[19,27,28]$ displayed by NP cells, together with decreased tissue cellularity and viability of remaining disc cells $[19,29]$.

The cells of the IVD produce a plethora of catabolic cytokines and chemokines [30-40] with highest expression seen in the NP and inner $\mathrm{AF}[30,33]$, expression within the outer AF is differentially expressed, with posterior AF tissue displaying higher expression of cytokines than the anterior AF [38]. There is increasing evidence supporting the role of a pivotal cytokine: Interleukin (IL)-1 in the pathogenesis of 
IVD degeneration [30,31,33,41-45]. With an increase in the production of the IL-1 agonists (IL- $1 \alpha$ and IL-1 $\beta$ ) and their active receptor IL-1RI, without a concordant increase in the natural inhibitors: IL-1 Receptor antagonist (IL-1Ra) or the decoy receptor: IL-1RII; within the cells of the NP and inner AF [33]. IL-1 has been shown to induce a plethora of catabolic events, which are linked to degradation of matrix [33,42], neuronal ingrowth and blood vessel ingrowth into the normally aneural and avascular disc $[41,46]$. Inhibition of IL-1 in IVD tissue in vitro has been shown to completely abrogate matrix degradation [42] whilst inhibition of TNF alpha had no such effect [42]. The importance of IL-1 in the pathogenesis of disc degeneration was furthered by the observation that spontaneous IVD degeneration occurred in a knockout mouse model where the natural inhibitor of IL-1 (IL-1Ra) was removed [47], which is further supported by the findings that polymorphisms in the IL-1 gene cluster increases the risk of IVD degeneration and low back pain [48-51]. These cellular changes during IVD degeneration lead to increased production of cytokines, matrix degrading enzymes, and leads to angiogenesis and nerve ingrowth which lead to sensitization of local nerves and painful stimuli. In addition release of cytokines from the degenerate disc, particularly following herniation leads to damage to the local nerve root, facet joints and adjacent vertebrae.

The cell mediated imbalance between normal matrix synthesis and degradation collectively results in a loss in the structural integrity of the NP with reduced hydration, reduced osmotic swelling pressure and overall reduced disc height [52]. This results in a diminished ability to withstand load and asymmetric distribution of compressive forces which leads to the formation of tears and fissures through the $\mathrm{AF}$, increasing the risk of disc herniation and providing an access route for the ingrowth of nerves and blood vessels associated with the sensation of chronic low back pain [41].

\section{Current Treatments for Degenerative Disc Disease}

Current practises for the treatment of low back pain are directed towards alleviating patient symptoms by conservative treatments including pain management, lifestyle adjustments and rehabilitation programs or surgical procedures to stabilise or remove the damaged tissue including discectomy and spinal fusion [53]. Despite this, these treatments are often associated with altered spine biomechanics and accelerated degenerative changes in adjacent discs $[54,55]$. Emerging treatments, driven by scientific research, have aimed to develop a biological approach which addresses the underlying pathogenesis of IVD degeneration. Many studies have explored the use of protein delivery to inhibit catabolic factors, promote matrix synthesis or reduce inflammation [32,56-59]. Despite this, the use of growth factors alone fails to treat the dysfunctional NP cells which display increased expression of catabolic factors [37], decreased synthesis of matrix components and increased senescence $[19,27,28]$, thus driving degeneration.

Consequently, a vast amount of research has focused on the use of cells, either alone, or together with biomaterial scaffolds, in order to repopulate the NP and simultaneously regenerate the matrix (Table 1). From a clinical perspective the aim is to restore/maintain spine biomechanics and alleviate patient symptoms, thus the use of cells in combination with a biomaterial scaffold to regenerate the matrix whilst restoring disc height appears to be an attractive strategy. Counter to this argument however is whether the regenerative capacity of cells is necessary or just an added complication, particularly for regulatory approval. Recent progress in tissue engineering has produced a magnitude of biomaterial scaffolds with improving resemblance both structurally and mechanically to the native NP, thus the development of a non-degradable biomaterial which mimics the functional biological matrix enough to provide the correct biomechanics may render the use of cells unnecessary. This review discusses the potential future treatment strategies of IVD degeneration including the use of cells or biomaterials, used individually or in combination, in order to answer the question: what is the ideal strategy for IVD regeneration?

\section{Cells Alone for Disc Degeneration}

The choice of cells to be used in IVD regeneration must be carefully considered to ensure successful therapeutic outcome. The implanted cells would need to meet certain requirements for adoption into clinical practice: they should be easily sourced and available in sufficient numbers to repopulate the NP; cells should be autologous where possible to minimise immunogenic risk and be capable of regenerating the correct biological matrix in order to functionally replicate disc metabolism and biomechanics [75]. The safety, effectiveness and viability of the cells must also be thoroughly characterised within the hypoxic and acidic disc microenvironment.

The use of autologous NP cells would be the ideal strategy and a variety of studies have shown them to be successful; both biologically to regenerate the NP matrix and clinically to reduce pain [76-78,]. Transplanted disc derived chondrocytes injected into degenerated IVDs of dogs were found to maintain retention of disc height and promote proteoglycan and collagen type II deposition [76]. Furthermore patients treated with autologous disc cell transplantation following discectomy, as part of the Euro Disc Randomised Trial, reported pain reduction after two years, in comparison to patients who did not receive autologous disc cell transplantation [76]; however, due to a lack of follow up on these patients, the long term effectiveness of this treatment cannot be accurately assessed. Furthermore, due to the low NP tissue cellularity, the harvesting of NP cells from more than one disc or in vitro expansion of cells for several weeks would be required to obtain a sufficient number of viable cells for transplantation. The use of autologous NP cells extracted from degenerate discs may also be inappropriate for regenerative purposes due to the increased expression of catabolic factors [37], decreased synthesis of normal matrix components and increased senescence displayed by these cells [19]. Finally the needle puncture which is currently used to extract autologous NP cells, has been shown to accelerate degenerative changes [79-81]. Non-autologous cell sources such as notochordal cells have also been investigated as potential candidates for NP regeneration $[82,83]$. Recently Potier et al., (2014) showed that notochordal cell-rich nucleus pulposus tissue stimulates matrix production by bone marrow stromal cells and NP cells, combined with increased NP cell proliferation and expression of NP phenotypic genes, thus promoting NP regeneration [84]. Despite this, the use of notochordal cells raises concerns regarding the allogeneic source required [11], the low cellular abundance [85], which may be insufficient to accommodate cell transplantation and a lack of understanding as to whether notochordal cells can differentiate into a biologically functioning NP cell [86].

Stem cells, particularly human Mesenchymal Stem Cells (hMSC) are an attractive cell choice for IVD regeneration since they can be extracted from a variety of adult tissues [87], they have proliferative capacity, have the ability to differentiate into multiple cell lineages [88] and avoid the ethical issues surrounding the use of embryonic stem 
Citation: Thorpe AA, Sammon C, Le Maitre CL (2015) 'Cell or Not to Cell' that is the Question: For Intervertebral Disc Regeneration? J Stem Cell Res Dev Ther 2: 003.

- Page 3 of 9 •

\begin{tabular}{|c|c|c|c|c|}
\hline Hydrogel Scaffold Material for NP & Culture conditions & Cellular or Acellular & Key Findings & Ref \\
\hline Gelatin hydrogel microspheres & In vivo (rabbit) & $\begin{array}{l}\text { Acellular with platelet-rich } \\
\text { plasma. }\end{array}$ & $\begin{array}{l}\text { Suppression of degeneration. Proteoglycan } \\
\text { production in NP and inner AF. }\end{array}$ & [60] \\
\hline $\begin{array}{l}\text { lonic Methacrylated gellan gum- } \\
\text { (iGG-MA) and photo-crosslinked } \\
\text { (phGG-MA) hydrogels }\end{array}$ & $\begin{array}{l}\text { In vitro } \\
\text { In vitro and In vivo (subcutaneous rat } \\
\text { model) } \\
\text { In vitro and In vivo (subcutaneous) }\end{array}$ & $\begin{array}{l}\text { Acellular and human Inter- } \\
\text { vertebral Disc (hIVD) cells } \\
\text { encapsulated. } \\
\text { Acellular and fibroblast cells } \\
\text { (L929 cells) and human } \\
\text { Intervertebral Disc (hIVD) } \\
\text { encapsulated hydrogels. } \\
\text { Human bone marrow-derived } \\
\text { MSCs and nasal chondrocytes }\end{array}$ & $\begin{array}{l}\text { Mechanical properties of cell-laden hydrogels } \\
\text { increased in comparison to acellular hydrogels. } \\
\text { Encapsulated cells found to be viable up to } 21 \\
\text { days of culturing. In vivo a thin fibrous capsule } \\
\text { was observed around implanted hydrogels. No } \\
\text { evidence of necrosis, calcification, and acute } \\
\text { inflammatory reaction. } \\
\text { Apoptosis observed in phGG-MA. } \\
\text { Evidence of chondrogenesis following subcuta- } \\
\text { neous implantation of iGG-MA. }\end{array}$ & [61] \\
\hline Atelocollagen ${ }^{\circledast}$ gel & In vivo: Rabbit. & Rabbit MSCs & $\begin{array}{l}\text { Degenerated discs of MSC-transplanted group } \\
\text { regained a disc height value of about } 91 \% \\
\text { compared to normal controls. Proteoglycan } \\
\text { production confirmed by histological and immu- } \\
\text { nological evaluation. }\end{array}$ & [64] \\
\hline Alginate & $\begin{array}{l}\text { In vitro under hypoxia }(2 \%) \text { and normoxia } \\
(20 \%)\end{array}$ & $\begin{array}{l}\text { Rat MSCs with transforming } \\
\text { growth factor- } \beta 1\end{array}$ & $\begin{array}{l}\text { Hypoxia induced upregulation of Glucose } \\
\text { transporter-3, matrix metalloproteinase- } 2 \text {, } \\
\text { collagen type II and type XI, and aggrecan } \\
\text { mRNA and protein expression was upregu- } \\
\text { lated, Transforming growth factor- } \beta \text { treatment } \\
\text { increased MAPK activity and Sox-9, aggrecan, } \\
\text { and collagen type II gene expression. }\end{array}$ & [65] \\
\hline Photocrosslinked alginate & $\begin{array}{l}\text { In vitro and In vivo (murine subcutaneous } \\
\text { model) }\end{array}$ & Bovine NP cells & $\begin{array}{l}\text { Production of aggrecan and collagen type II. } \\
\text { Cellular hydrogels were mechanically superior } \\
\text { to acellular hydrogels. } \\
\text { Young's modulus of cellular hydrogels signifif- } \\
\text { cantly increased from } 4 \text { to } 8 \text { weeks. }\end{array}$ & [66] \\
\hline $\begin{array}{l}\text { Type II collagen and Hyaluronic } \\
\text { Acid (HA). }\end{array}$ & In vitro & $\begin{array}{l}\text { Rat MScs with and without } \\
\text { differentiating medium. }\end{array}$ & $\begin{array}{l}\text { Increased aggrecan and collagen type II with } \\
\text { decreased collagen I in hydrogel constructs } \\
\text { where differentiating medium used. }\end{array}$ & [67] \\
\hline $\begin{array}{l}\left.\text { Hyaluronan gel (Durolane }{ }^{\circledast}\right) \text {, hydro- } \\
\text { gel (Puramatrix }) \text {, and tissue-glue } \\
\text { gel (TISSEEL }{ }^{\oplus} \text { ) }\end{array}$ & In vivo mini pigs & $\begin{array}{l}\text { human Mesenchymal Cells } \\
\text { (hMSCs), IVD cells (hDCs), } \\
\text { and Chondrocytes (hCs) }\end{array}$ & $\begin{array}{l}\text { Xenotransplanted } \mathrm{hMSCs} \text { and } \mathrm{hCs} \text { survived } \\
\text { in porcine IVDs for } 6 \text { months and produced } \\
\text { collagen II in all six animals. } \\
\text { Following six months pronounced endplate } \\
\text { changes, and bone mineralisation indicating } \\
\text { severe IVD degeneration were observed within } \\
\text { all cellular and acellular hyaluronan gel carrier } \\
\text { groups. }\end{array}$ & [68] \\
\hline $\begin{array}{l}\text { Chitosan-GLycerophosphate (C/ } \\
\text { Gp) hydrogel }\end{array}$ & In vitro & $\begin{array}{l}\text { Human MSCs in standard } \\
\text { medium. }\end{array}$ & $\begin{array}{l}\text { Production of proteoglycans and collagens in a } \\
\text { ratio which more closely resembles that of NP } \\
\text { cells than articular chondrocytes. }\end{array}$ & [69] \\
\hline $\begin{array}{l}\text { Hyaluronan-poly (N-isopropy- } \\
\text { lacrylamide) hydrogel. }\end{array}$ & $\begin{array}{l}\text { In vitro under hypoxia and ex vivo bovine } \\
\text { caudal discs }\end{array}$ & $\begin{array}{l}\text { hMSCs chondropermissive } \\
\text { medium alone and with the } \\
\text { supplementation of transform- } \\
\text { ing growth factor } \beta 1 \text { or Growth } \\
\text { and Differentiation Factor } 5 \\
\text { (GDF-5) }\end{array}$ & $\begin{array}{l}\text { All HA, HA-pNIPAM and their degradation } \\
\text { products were cytocompatible to NP cells. } \\
\text { Glycosaminoglycan synthesis was similar in } \\
\text { HA-pNIPAM and alginate gels. } \\
\text { Higher expression of hyaluronan synthases } \\
\text { and lower expression of COLI and COLII } \\
\text { mRNA were noted in cells cultured in HA-pNI- } \\
\text { PAM. } \\
\text { Higher GAG/DNA ratio and higher collagen } \\
\text { type II, SOX9, cytokeratin-19, cluster of } \\
\text { differentiation 24, and forkhead box protein F1 } \\
\text { expressions were found for hMSCs cultured } \\
\text { in HA-pNIPAM compared with those cultured } \\
\text { in alginate. } \\
\text { Ex vivo, direct combination of HA-pNIPAM with } \\
\text { the disc environment induced a stronger disc- } \\
\text { like differentiation of hMSCs than predifferen- } \\
\text { tiation of hMSCs followed by their delivery to } \\
\text { the discs. }\end{array}$ & [70] \\
\hline $\begin{array}{l}\text { photo-curable (pHEMA-co-APMA } \\
\text { grafted with Polyamidoamine } \\
\text { (PAA)) }\end{array}$ & In vitro & $\begin{array}{l}\text { hMSC with standard and } \\
\text { chondrogenic differentiating } \\
\text { medium. }\end{array}$ & $\begin{array}{l}\text { Elevated expression levels of aggrecan and } \\
\text { collagen II when cultured in chondrogenic } \\
\text { media under hypoxic conditions, in comparison } \\
\text { with culture in hMSC media for } 14 \text { days. } \\
\text { Significant decrease in stiffness and modulus } \\
\text { values of cellular hydrogels in comparison with } \\
\text { acellular hydrogels at both day } 7 \text { and day } 14 \text {. } \\
\text { Increasing cytoxicity with increasing UV } \\
\text { exposure time. }\end{array}$ & [72] \\
\hline
\end{tabular}




\begin{tabular}{|l|l|l|l|}
\hline $\begin{array}{l}\text { Chitosan/Gelatin//-Glycerol } \\
\text { Phosphate (C/G/GP) disodium salt } \\
\text { hydrogels }\end{array}$ & In vitro & Rabbit NP cells. & $\begin{array}{l}\text { Increased gene expression of aggrecan and } \\
\text { type II collagen and increased glycosamino- } \\
\text { glycan production in NP cells cultured in the } \\
\text { hydrogel in comparision to monolayer controls. }\end{array}$ \\
\hline $\begin{array}{l}\text { Gelatin/chitosan/glycerol phos- } \\
\text { phate hydrogel with ferulic acid. }\end{array}$ & In vitro & $\begin{array}{l}\text { Rabbit NP cells } \\
\text { Up-regulation of MMP-3 and up-regulation } \\
\text { aggrecan and type II collagen in mRNA level. } \\
\text { The sulfated-glycosaminoglycan production } \\
\text { was increased and the apoptosis was inhibited } \\
\text { in the post-treatment group. }\end{array}$ & \begin{tabular}{l}
{$[74]$} \\
\hline
\end{tabular}
\end{tabular}

Table 1: Hydrogels used for NP regeneration.

cells. A number of hMSC sources have been investigated including bone marrow, periosteum, synovial membrane and adipose tissue [89-91]. Studies have suggested that the source of MSCs are critical to the clinical outcome with improved expansive and chrondrogenic differentiation potential for cartilage repair in synovial membrane and adipose tissue derived MSCs in comparison to bone marrow derived MSCs [87-92]. Recently patient matched bone marrow derived and adipose derived MSCs were compared to determine their differentiation capacity towards NP cells following stimulation with the growth factor GDF-6, which demonstrated adipose derived MSCs displayed micromechanical properties more akin to the NP than the bone marrow derived MSCs suggesting these cells may be more suited to NP regeneration [93].

Increasing evidence has shown that hMSC are able to differentiate into NP like cells and produce a biologically functional NP matrix consisting of proteoglycans and collagen type II [94-97]. Studies have also shown that co-culture of hMSCs and NP cells not only enhances NP cell differentiation, but also restores normal NP cell function and increases NP cell proliferation, thus aiding the repair process [98-100]. Despite limited publications on the use of MSCs alone for the regeneration of the IVD, successful outcomes have been reported, particularly in small animal models where transplanted bone marrow derived MSCs have been shown to undergo chondrogenesis with consequential deposition of proteoglycans and collagen type II in both rabbit IVD [97] and rat coccygeal discs [101]. Similarly expression of discogenic genes with matrix staining for aggrecan and collagen type II occurred where hMSCs were injected into an explant NP tissue model [102].

The success of hMSCs alone for the regeneration of the IVD in small animal models, has not always been replicated in large animal models. Henriksson et al., (2009) investigated the survival and differential capacity of hMSCs into injured porcine discs both alone and with a hydrogel carrier [103]. hMSCs were shown to survive and express typical chondrogenic markers, but immunopositivity for aggrecan and collagen type II was only observed in cell/hydrogel discs. Furthermore, low cell survival and the formation of a collagen type I/II scar tissue has been reported following 3 months after in vivo injection of allogenic disc derived MSCs [104]. Collectively these results suggest that transplantation of cells alone into a large animal model is not sufficient to produce the correct functional matrix, possibly due to the larger disc size giving a greater nutrient diffusion distance, inducing nutrient deprivation for the transplanted cells. Furthermore concerns, regarding MSC leakage following injection, with consequential undesirable bone formation, has been demonstrated as a potential side-effect of this therapeutic strategy, thus highlighting the potential need for cell carrier systems or annulus-sealing technologies to avoid the pitfalls of this treatment approach [105]. Despite this, results from a small human trial, whereby 10 patients with disc degeneration but intact annulus fibrosus, received an injection of autologous expanded bone marrow derived MSCs, reported significant improvements in pain and disability 12 months following treatment [96]. However these patients demonstrated no evidence of improved disc height [86]. These results suggest that the use of hMSCs transplanted into the IVD alone has limitations but may be improved with the use of an appropriate biomaterial scaffold.

The major drawback of MSC based strategies is a lack of understanding of the normal NP cell phenotype. The majority of studies, including those which have been discussed in this review, define NP cell differentiation using traditional chondrogenic genes such as Sex Determining Region (SRY) box 9, collagen type II and aggrecan [94,102,106,107]. However cells and tissues of articular cartilage and NP demonstrate significant differences in terms of morphology, ECM disposition and biomechanical behaviour [5]; consequently, the identification of differential NP markers which can be used to inform and thoroughly assess MSC differentiation is the current focus of many research studies [14-18,108].

\section{Acellular Biomaterials for Disc Degeneration}

Acellular biomaterial scaffolds provide a more simplistic therapeutic alternative to cellular strategies without the added complications of cell harvesting. Similar to cellular strategies, an increasingly prevalent issue with acellular strategies is whether one acellular treatment will accommodate all stages of degeneration. Based on trends in current research, one design strategy for acellular treatments could include non-invasive injectable monophasic hydrogels combined with inhibitors of degeneration or growth factors during early stages of degeneration to repair the NP [60], injectable biphasic scaffolds to repair the NP and AF in mid stages of degeneration and Tissue Engineered Total Disc Replacements (TE-TDR) in severely degenerate cases [109].

The use of hydrogels as delivery systems of catabolic inhibitors and growth factors to provide an acellular treatment strategy for NP repair has been successfully reported [60,110-112]. It must be noted however that a recent focus on the use of hydrogels as delivery systems for both cells and biomolecules is evident, thus the effectiveness of catabolic inhibitors and/or growth factors alone within monophasic scaffolds to repair the NP has not been thoroughly assessed. There is a clear rationale for this however since a regenerative source would need to be combined with mediators to inhibit degeneration to fully restore normal disc function.

The main challenge in the development of monophasic acellular hydrogels for the treatment of IVD regeneration is ensuring sufficient mechanical properties to withstand the load forces exerted on the spinal column. Silva-Correia et al., (2013) investigated the mechanical properties of acellular and cell laden ionic- and photo-crosslinked methacrylated gellan gum hydrogels; mechanical integrity of acellular hydrogels was maintained throughout the 21 day culture period, however cell-laden hydrogels were mechanically superior [61]. 
Total Disc Replacement (TDR), which consists of polyethylene on metal, or metal on metal implants engineered to resemble a low friction ball and socket joint, is currently considered as an alternative treatment strategy to spinal fusion [113]. This method does not avoid invasive surgery since the excision of the degenerate disc is unavoidable, however does restore some mobility to the intervertebral joint which could reduce the risk of adjacent disc degeneration [114]. Considerable debate as to whether TDR is more efficacious than spinal fusion still remains. A Cochrane review [114] systematically assessed the efficacy outcomes of TDR in terms of motion preservation, adjacent disc degeneration and patient satisfaction and concluded that no evidence of superior clinical outcomes between TDR and spinal fusion was observed. Furthermore the authors of this review advised that caution should be taken when considering the adoption of TDR into wide scale clinical practice since the effectiveness of TDR is patient dependent and complications may arise years following treatment [114]. Despite this, Siepe et al., (2010) conducted a 5-10 year follow up of patients whom had undergone TDR as treatment for disc degeneration and concluded that TDR were a viable treatment alternative to spinal fusion [115]. It is clear that both spinal fusion and TDR have limitations, however the development of novel polymeric implants which replicate the biomechanics of the natural disc could be considered as an effective acellular strategy, particularly in severe stages of degeneration, where the use of monophasic biomaterials or cells alone would be insufficient to provide the biological functions of all anatomical regions of the IVD. In particular novel viscoelastic TDR materials have been developed which replicate the flexibility, stiffness and stress/stain dynamics of native disc, thus could be used as a more mechanically efficacious implant material for TDR in the future [109,116].

Despite the development of novel polymeric materials which could be used as a single material implant for TDR, more effective outcomes may be achieved with a Tissue Engineered (TE) strategy, including a combination of biomaterials in order to effectively replicate the total IVD (NP, AF, CEP). To date, biphasic scaffolds, seeded with cells, have shown potential for regeneration of two of the anatomical regions of the IVD (NP and AF) [117,118]. Furthermore, calcium polyphosphate substrates have been used to engineer cartilaginous end plates $[119,120]$. The success of combining multiple biomaterials as an effective acellular strategy is dependent on replicating the correct biomechanical properties of the NP, AF and CEP. A TE-TDR which replicates all three anatomical regions is yet to be developed, however the studies discussed here demonstrate clear progression in the aim to develop a functional spinal unit.

\section{Cellular Biomaterials for Disc Degeneration}

As discussed, the use of cells alone or acellular biomaterials for disc repair, individually have shown some success for the treatment of IVD degeneration, both, however provide different clinical outcomes, such as the regenerative capacity provided by the use of cells and the mechanical support provided by acellular biomaterial scaffolds; consequently current research has focused on the use of cellular biomaterial scaffolds (Table 1) which provide biomechanical support whilst simultaneously regenerating the NP matrix, thus resulting in an integrated and biologically functioning tissue. The ideal load bearing biomaterial scaffold for IVD regeneration, which meets all requirements in terms of biocompatibility, bioactivity, mechanical properties and injectability, is yet to be produced. However a limited number of studies have demonstrated success in terms of hMSC encapsulation and differentiation towards the NP lineage.
Traditionally the biocompatability of natural polymer scaffolds has been an appealing choice for NP repair, including collagen [121], alginate [65], gelatine [60], hylauronan [67,68], chitosan-glycerophosphate $[94,107]$ and thermoresponsive hyaluronic acid (Table 1) [71]. However the use of natural polymers raises concerns regarding batch variation and immunogenic risk; consequently a number of studies have looked to develop synthetic polymer scaffolds which have the added advantage of synthesis control, large scale production and the ability to tailor bioactivity, mechanical properties and degradation rates. However toxic chemicals including initiators, stabilisers, organic solvents, cross linkers, emulsifiers and unreacted monomers which may be used in the synthesis and polymerisation of synthetic hydrogels pose a significant safety risk [64,122]. An ideal biomaterial scaffold, particularly in early stages of degeneration when it may not be necessary to excise the degenerate disc, would be an injectable hydrogel which delivers cells and biomolecules followed by in situ solidification; however this again poses significant challenges since potentially toxic unreacted material may need to be injected directly into the body, for this reason a variety of hydrogel systems with different fabrication techniques have been investigated [122]. Encapsulation and subsequent discogenic differentiation of MSCs has been performed in synthetic photo-crosslinked hydrogels, however apoptosis [63] and cytotoxicity with increasing UV exposure time [116] has been observed using this fabrication technique; thus raising concerns regarding the use of photocrosslinking not only to the implanted cells but also to surrounding tissues during delivery [72]. An attractive alternative to photo-crosslinked hydrogels is the use of thermo-reversible hydrogels which undergo liquid to gel transition at body temperature $[71,73,123]$. Studies have demonstrated successful biocompatibility, discogenic differentiation and deposition of an NP like matrix by MSCs cultured in thermo-responsive Chitosan-Glycerophosphate (C/Gp) hydrogels [94,124]. Further work by Cheng et al., (2013) showed sustained release of the antioxidant ferulic acid in thermosensitive Chitosan-Gelatin-Glycerol Phosphate hydrogels, with consequential reduction in catabolic mediators and increased synthesis of normal matrix components, thus could be combined with cells to enhance NP regeneration [74]. Alternatively the use of a thermo-reversible Hyaluronan-poly(N-Isopropylacrylamide) (HA-pNIPAM) hydrogel has been recently shown to induce discogenic differentiation of MSCs with production of an NP like matrix under hypoxic conditions $[71,70]$.

The majority of cellular hydrogel systems have been designed for NP regeneration (Table 1) since this is the main region which undergoes significant cellular and matrix changes during degeneration of the IVD $[19,20]$. Despite this, NP repair is likely to be insufficient, particularly in severely degenerate cases where tears in the AF may result in extrusion of the implanted biomaterial and/or cells; consequently a variety of studies have investigated biphasic scaffolds which aim to repair the AF and NP simultaneously $[118,125,126]$. The use of electrospinning polymeric material has attracted significant interest in order to the replicate the highly organised native $\mathrm{AF}$ structure [127]. Lazebnik et al., (2011) used a biomimetic strategy by combining porcine chondrocyte cell seeded agarose gel surrounded by cell seeded electrospun polycaprolactine fibres and observed that cells were viable, well distributed and orientated themselves in the direction of the fibres [128]. Successful incorporation of growth factors to enhance regeneration has also been shown in electrospun scaffolds [129]. Furthermore, biphasic scaffolds consisting of a hydrogel NP centre surrounded by a polymeric electrospun AF 
scaffold have been shown to possess superior mechanical properties $[128,130]$.

Despite recent success of NP regeneration in vitro and in small animal models, there are still significant challenges that remain before such studies can be scaled up to pre-clinical analysis. Unresolved questions include: what is the ideal cell type and source? Is the use of a biomaterial scaffold necessary? At what stage of degeneration is regenerative cell therapy clinically applicable? Furthermore, Reitmeir et al., (2014) conducted an in vivo efficacy study whereby bone marrow derived MSCS were encapsulated within hydrogels, incorporated with anti-angiogenic factors and implanted into ovine disc; following 12 weeks no significant difference in biomechanical properties was observed between implanted and untreated discs and disc height and degeneration score deteriorated for all implant treated discs [131]. Thus caution should be taken when considering in vitro results since the complex molecular and biomechanical disc microenvironment makes replication of in vitro results in vivo extremely difficult.

\section{Personalized Therapies}

The recent advances in quantitative MRI imaging [132] may one day enable the clinician to identify early stages of degeneration which could be targeted by cell based therapies alone, whilst it is likely mid stage degeneration may require cells together with biomaterials. However, certain patients may not be suitable for cell based therapies and acellular approaches may be more suitable, such as those with end plate calcification. With the advent of specialist imaging modalities personalised therapies may become possible.

\section{Discussion and Future Outlooks}

When considering the most effective treatment for IVD degeneration it is important to define and diagnose the IVD by stage of degeneration. A multitude of hydrogel scaffolds for IVD degeneration has been proposed each of which is competing to provide the ideal therapeutic strategy. It is clear however that one scaffold will not suffice; clinicians should be presented with a variety of treatment options, both cellular and acellular, in order deliver the most efficacious, safe and cost effective treatment for the stage of degeneration. In order to reduce the amount of current surgical practise on IVD repair, which at present is clinically counter intuitive, scientific research into IVD degeneration must remain at the forefront in order to bridge the gap between research therapeutics and adoption into clinical practise.

\section{References}

1. Schultz A, Warwick D, Berkson M, Nachemson A (1979) Mechanical properties of human lumbar spine motion segments-Part I: Responses in flexion, extension, lateral bending, and torsion. J Biomech Eng 101: 46-52.

2. K B (1989) The lumbar spine and back pain edited by MIV Jayson Churchill Livingstone, UK, 1987, 3rd edn, 463pp, £65. Clin Biomech (Bristol, Avon) 4: 126.

3. Roberts S, Menage J, Urban JP (1989) Biochemical and structural properties of the cartilage end-plate and its relation to the intervertebral disc. Spine (Phila Pa 1976) 14: 166-174.

4. Shankar H, Scarlett JA, Abram SE (2009) Anatomy and pathophysiology of intervertebral disc disease. Techniques in Regional Anesthesia and Pain Management 13: 67-75.

5. Mwale F, Roughley P, Antoniou J (2004) Distinction between the extracellular matrix of the nucleus pulposus and hyaline cartilage: a requisite for tissue engineering of intervertebral disc. Eur Cell Mater 8: 58-63.
6. Dolan P, Adams MA (2001) Recent advances in lumbar spinal mechanics and their significance for modelling. Clin Biomech (Bristol, Avon) 1: 8-16.

7. Roughley PJ (2004) Biology of intervertebral disc aging and degeneration: involvement of the extracellular matrix. Spine (Phila Pa 1976) 29: 26912699 .

8. Hunter CJ, Matyas JR, Duncan NA (2003) The three-dimensional architecture of the notochordal nucleus pulposus: novel observations on cell structures in the canine intervertebral disc. J Anat 202: 279-291.

9. Hunter CJ, Matyas JR, Duncan NA (2004) Cytomorphology of notochordal and chondrocytic cells from the nucleus pulposus: a species comparison. $J$ Anat 205: 357-362.

10. Chen J, Yan W, Setton LA (2006) Molecular phenotypes of notochordal cells purified from immature nucleus pulposus. Eur Spine J 15 Suppl 3: S303-311.

11. Hunter CJ, Matyas JR, Duncan NA (2003) The notochordal cell in the nucleus pulposus: a review in the context of tissue engineering. Tissue Eng 9: 667-677.

12. Kim KW, Ha KY, Lee JS, Nam SW, Woo YK, et al. (2009) Notochordal cells stimulate migration of cartilage end plate chondrocytes of the intervertebral disc in in vitro cell migration assays. Spine J 9: 323-329.

13. Yang F, Leung VY, Luk KD, Chan D, Cheung KM (2009) Injury-induced sequential transformation of notochordal nucleus pulposus to chondrogenic and fibrocartilaginous phenotype in the mouse. J Pathol 218: 113-121.

14. Minogue BM, Richardson SM, Zeef LA, Freemont AJ, Hoyland JA (2010) Characterization of the human nucleus pulposus cell phenotype and evaluation of novel marker gene expression to define adult stem cell differentiation. Arthritis Rheum 62: 3695-3705.

15. Rutges J, Creemers LB, Dhert W, Milz S, Sakai D, et al. (2010) Variations in gene and protein expression in human nucleus pulposus in comparison with annulus fibrosus and cartilage cells: potential associations with aging and degeneration. Osteoarthritis Cartilage 18: 416-423.

16. Rodrigues-Pinto R, Richardson SM, Hoyland JA (2013) Identification of novel nucleus pulposus markers: Interspecies variations and implications for cell-based therapiesfor intervertebral disc degeneration. Bone Joint Res 2: 169-178.

17. Choi H, Johnson ZI, Risbud MV1 (2015) Understanding Nucleus Pulposus Cell Phenotype: A Prerequisite for Stem Cell Based Therapies to Treat Intervertebral Disc Degeneration. Curr Stem Cell Res Ther.

18. Risbud MV, Schoepflin ZR, Mwale F, Kandel RA, Grad S, et al. (2015) Defining the phenotype of young healthy nucleus pulposus cells: Recommendations of the Spine Research Interest Group at the 2014 annual ORS meeting. J Orthop Res 33: 283-293.

19. Le Maitre CL, Freemont AJ, Hoyland JA (2007) Accelerated cellular senescence in degenerate intervertebral discs: a possible role in the pathogenesis of intervertebral disc degeneration. Arthritis Res Ther 9: 45.

20. Le Maitre CL, Pockert A, Buttle DJ, Freemont AJ, Hoyland JA (2007) Matrix synthesis and degradation in human intervertebral disc degeneration. Biochem Soc Trans 35: 652-655.

21. Inkinen RI, Lammi MJ, Lehmonen S, Puustjärvi K, Kääpä E, et al. (1998) Relative increase of biglycan and decorin and altered chondroitin sulfate epitopes in the degenerating human intervertebral disc. J Rheumatol 25: 506-514.

22. Cs-Szabo G, Ragasa-San Juan D, Turumella V, Masuda K, Thonar EJ, et al. (2002) Changes in mRNA and protein levels of proteoglycans of the anulus fibrosus and nucleus pulposus during intervertebral disc degeneration. Spine (Phila Pa 1976) 27: 2212-2219.

23. Le Maitre CL, Freemont AJ, Hoyland JA (2004) Localization of degradative enzymes and their inhibitors in the degenerate human intervertebral disc. J Pathol 204: 47-54. 
24. Pockert AJ, Richardson SM, Le Maitre CL, Lyon M, Deakin JA, et al. (2009) Modified expression of the ADAMTS enzymes and tissue inhibitor of metalloproteinases 3 during human intervertebral disc degeneration. Arthritis Rheum 60: 482-491.

25. Gruber HE, Hanley EN Jr (1998) Analysis of aging and degeneration of the human intervertebral disc. Comparison of surgical specimens with normal controls. Spine (Phila Pa 1976) 23: 751-757.

26. Ding F, Shao ZW, Xiong LM (2013) Cell death in intervertebral disc degeneration. Apoptosis 18: 777-785.

27. Gruber HE, Ingram JA, Norton HJ, Hanley EN Jr (2007) Senescence in cells of the aging and degenerating intervertebral disc: immunolocalization of senescence-associated beta-galactosidase in human and sand rat discs. Spine (Phila Pa 1976) 32: 321-327.

28. Roberts S, Evans EH, Kletsas D, Jaffray DC, Eisenstein SM (2006) Senescence in human intervertebral discs. Eur Spine J 3: 312-316.

29. Kim KW, Chung HN, Ha KY, Lee JS, Kim YY (2009) Senescence mechanisms of nucleus pulposus chondrocytes in human intervertebral discs. Spine J 9: 658-666

30. Phillips KL, Chiverton N, Michael AL, Cole AA, Breakwell LM, et al. (2013) The cytokine and chemokine expression profile of nucleus pulposus cells: implications for degeneration and regeneration of the intervertebral disc. Arthritis Res Ther 15: 213

31. Wang J, Tian Y, Phillips KL, Chiverton N, Haddock G, et al. (2013) Tumor necrosis factor a and interleukin-1 $\beta$-dependent induction of CCL3 expression by nucleus pulposus cells promotes macrophage migration through CCR1. Arthritis \& Rheumatism 65: 832-842.

32. Le Maitre CL, Hoyland JA, Freemont AJ (2007) Interleukin-1 receptor antagonist delivered directly and by gene therapy inhibits matrix degradation in the intact degenerate human intervertebral disc: an in situ zymographic and gene therapy study. Arthritis Res Ther 9: 83.

33. Le Maitre CL, Freemont AJ, Hoyland JA (2005) The role of interleukin-1 in the pathogenesis of human intervertebral disc degeneration. Arthritis Res Ther 7: 732-745.

34. Kepler CK, Markova DZ, Dibra F, Yadla S, Vaccaro AR, et al. (2013) Ex pression and relationship of proinflammatory chemokine RANTES/CCL5 and cytokine IL-1 $\beta$ in painful human intervertebral discs. Spine (Phila Pa 1976) 38: 873-880.

35. Wang H, Tian Y, Wang J, Phillips KL, Binch AL, et al. (2013) Inflammatory cytokines induce NOTCH signaling in nucleus pulposus cells: implications in intervertebral disc degeneration. J Biol Chem 288: 16761-16774.

36. Shamji MF, Setton LA, Jarvis W, So S, Chen J, et al. (2010) Proinflammatory cytokine expression profile in degenerated and herniated human intervertebral disc tissues. Arthritis Rheum 62: 1974-1982.

37. Le Maitre CL, Hoyland JA, Freemont AJ (2007) Catabolic cytokine expression in degenerate and herniated human intervertebral discs: IL-1beta and TNFalpha expression profile. Arthritis Res Ther 9: 77.

38. Koerner JD, Markova DZ, Yadla S, Mendelis J, Hilibrand A, et al. (2014) Differential gene expression in anterior and posterior annulus fibrosus. Spine (Phila Pa 1976) 39: 1917-1923.

39. Risbud MV, Shapiro IM (2014) Role of cytokines in intervertebral disc degeneration: pain and disc content. Nat Rev Rheumatol 10: 44-56.

40. Kepler CK, Markova DZ, Hilibrand AS, Vaccaro AR, Risbud MV, et al. (2013) Substance P stimulates production of inflammatory cytokines in human disc cells. Spine (Phila Pa 1976) 38: 1291-1299.

41. Binch AL, Cole AA, Breakwell LM, Michael AL, Chiverton N, et al. (2014) Expression and regulation of neurotrophic and angiogenic factors during human intervertebral disc degeneration. Arthritis Res Ther 16: 416.

42. Hoyland JA, Le Maitre C, Freemont AJ (2008) Investigation of the role of $\mathrm{IL}-1$ and TNF in matrix degradation in the intervertebral disc. Rheumatology (Oxford) 47: 809-814.
43. Lee JM, Song JY, Baek M, Jung HY, Kang H, et al. (2011) Interleukin-1ß induces angiogenesis and innervation in human intervertebral disc degeneration. J Orthop Res 29: 265-269.

44. Studer RK, Gilbertson LG, Georgescu H, Sowa G, Vo N, et al. (2008) p38 MAPK inhibition modulates rabbit nucleus pulposus cell response to IL-1. J Orthop Res 26: 991-998.

45. Phillips K, Chiverton N, Michael A, Cole A, Breakwell L, et al. (2015) Potential Roles of Cytokines and Chemokines in Human Intervertebral Disc Degeneration: Interleukin-1 is a Master Regulator of catabolic processes. Osteoarthritis and Cartilage.

46. Krock E, Rosenzweig DH, Chabot-Doré AJ, Jarzem $\mathrm{P}$, Weber $\mathrm{MH}$, et al. (2014) Painful, degenerating intervertebral discs up-regulate neurite sprouting and CGRP through nociceptive factors. J Cell Mol Med 18: 1213-1225.

47. Phillips KL, Jordan-Mahy N, Nicklin MJ, Le Maitre CL (2013) Interleukin-1 receptor antagonist deficient mice provide insights into pathogenesis of human intervertebral disc degeneration. Ann Rheum Dis 72: 1860-1867.

48. Karppinen J, Solovieva S, Luoma K, Raininko R, Leino-Arjas P, et al. (2009) Modic changes and interleukin 1 gene locus polymorphisms in occupational cohort of middle-aged men. Eur Spine J 18: 1963-1970.

49. Solovieva S, Leino-Arjas P, Saarela J, Luoma K, Raininko R, et al. (2004) Possible association of interleukin 1 gene locus polymorphisms with low back pain. Pain 109: 8-19.

50. Solovieva S, Kouhia S, Leino-Arjas P, Ala-Kokko L, Luoma K, et al. (2004) Interleukin 1 polymorphisms and intervertebral disc degeneration. Epidemiology 15: 626-633.

51. Solovieva S, Lohiniva J, Leino-Arjas P, Raininko R, Luoma K, et al. (2006) Intervertebral disc degeneration in relation to the COL9A3 and the IL-1ss gene polymorphisms. Eur Spine J 15: 613-619.

52. Urban JP, McMullin JF (1988) Swelling pressure of the lumbar intervertebral discs: influence of age, spinal level, composition, and degeneration. Spine (Phila Pa 1976) 13: 179-187.

53. Le Maitre CL, Binch AL, Thorpe AA, Hughes SP (2015) Degeneration of the intervertebral disc with new approaches for treating low back pain. $J$ Neurosurg Sci 59: 47-61.

54. Eck JC, Humphreys SC, Lim TH, Jeong ST, Kim JG, et al. (2002) Biomechanical study on the effect of cervical spine fusion on adjacent-level intradiscal pressure and segmental motion. Spine (Phila Pa 1976) 27: 24312434

55. Lund T, Oxland TR (2011) Adjacent level disk disease--is it really a fusion disease? Orthop Clin North Am 42: 529-541.

56. Cao D, Quan Z, Jiang D, Luo X, Zhong W, et al. (2012) [Effect of adenovirus human bone morphogenetic protein 4 on human degenerative lumbar intervertebral disc cells]. Zhongguo Xiu Fu Chong Jian Wai Ke Za Zhi 26: 1442-1447.

57. Tim Yoon S, Su Kim K, Li J, Soo Park J, Akamaru T, et al. (2003) The effect of bone morphogenetic protein-2 on rat intervertebral disc cells in vitro. Spine (Phila Pa 1976) 28: 1773-1780.

58. Gorth DJ, Mauck RL, Chiaro JA, Mohanraj B, Hebela NM, et al. (2012) IL-1ra delivered from poly(lactic-co-glycolic acid) microspheres attenuates IL-1 $\beta$-mediated degradation of nucleus pulposus in vitro. Arthritis Res Ther 14: 179.

59. Le Maitre CL, Freemont AJ, Hoyland JA (2009) Expression of cartilage-derived morphogenetic protein in human intervertebral discs and its effect on matrix synthesis in degenerate human nucleus pulposus cells. Arthritis Res Ther 11: 137.

60. Nagae M, Ikeda T, Mikami Y, Hase H, Ozawa H, et al. (2007) Intervertebral disc regeneration using platelet-rich plasma and biodegradable gelatin hydrogel microspheres. Tissue Eng 13: 147-158. 
61. Silva-Correia J, Gloria A, Oliveira MB, Mano JF, Oliveira JM, et al. (2013) Rheological and mechanical properties of acellular and cell-laden methacrylated gellan gum hydrogels. J Biomed Mater Res A 101: 3438-3446.

62. Silva-Correia J, Zavan B, Vindigni V, Silva TH, Oliveira JM, et al. (2013) Biocompatibility evaluation of ionic- and photo-crosslinked methacrylated gellan gum hydrogels: in vitro and in vivo study. Adv Healthc Mater 2: 568-575.

63. Tsaryk R, Silva-Correia J, Oliveira JM, Unger RE, Landes C, et al. (2014) Biological performance of cell-encapsulated methacrylated gellan gum-based hydrogels for nucleus pulposus regeneration. J Tissue Eng Regen Med.

64. Bryant SJ, Nuttelman CR, Anseth KS (2000) Cytocompatibility of UV and visible light photoinitiating systems on cultured $\mathrm{NIH} / 3 \mathrm{~T} 3$ fibroblasts in vitro. J Biomater Sci Polym Ed 11: 439-457.

65. Risbud MV, Albert TJ, Guttapalli A, Vresilovic EJ, Hillibrand AS, et al. (2004) Differentiation of mesenchymal stem cells towards a nucleus pulposus-like phenotype in vitro: implications for cell-based transplantation therapy. Spine (Phila Pa 1976) 29: 2627-2632.

66. Chou Al, Nicoll SB (2009) Characterization of photocrosslinked alginate hydrogels for nucleus pulposus cell encapsulation. J Biomed Mater Res A 91: 187-194.

67. Calderon L, Collin E, Velasco-Bayon D, Murphy M, O'Halloran D, et al. (2010) Type II collagen-hyaluronan hydrogel--a step towards a scaffold for intervertebral disc tissue engineering. Eur Cell Mater 20: 134-148.

68. Henriksson H, Hagman M, Horn M, Lindahl A, Brisby H (2011) Investigation of different cell types and gel carriers for cell-based intervertebral disc therapy, in vitro and in vivo studies. J Tissue Eng Regen Med.

69. Richardson SM, Hughes N, Hunt JA, Freemont AJ, Hoyland JA (2008) Human mesenchymal stem cell differentiation to NP-like cells in chitosan-glycerophosphate hydrogels. Biomaterials 29: 85-93.

70. Peroglio M, Grad S, Mortisen D, Sprecher CM, Illien-Jünger S, et al. (2012) Injectable thermoreversible hyaluronan-based hydrogels for nucleus pulposus cell encapsulation. Eur Spine J 6: 839-849.

71. Peroglio M, Eglin D, Benneker LM, Alini M, Grad S (2013) Thermoreversible hyaluronan-based hydrogel supports in vitro and ex vivo disc-like differentiation of human mesenchymal stem cells. Spine J 13: 1627-1639.

72. Kumar D, Gerges I, Tamplenizza M, Lenardi C, Forsyth NR, Liu Y (2014) Three-dimensional hypoxic culture of human mesenchymal stem cells encapsulated in a photocurable, biodegradable polymer hydrogel: A potential injectable cellular product for nucleus pulposus regeneration. Acta biomaterialia 10: 3463-3474.

73. Cheng Y, Yang S, Su W, Chen Y, Yang K, et al (2009) Thermosensitive chitosan-gelatin-glycerol phosphate hydrogels as a cell carrier for nucleus pulposus regeneration: an in vitro study. Tissue Engineering Part $A$ 16: 695-703.

74. Cheng YH, Yang SH, Liu CC, Gefen A, Lin FH (2013) Thermosensitive hydrogel made of ferulic acid-gelatin and chitosan glycerophosphate. Carbohydr Polym 92: 1512-1519.

75. Anderson DG, Albert TJ, Fraser JK, Risbud M, Wuisman P, et al. (2005) Cellular therapy for disc degeneration. Spine (Phila Pa 1976) 30: 14-19.

76. Hohaus C, Ganey T, Minkus $Y$ and Meisel H (2008) Cell transplantation in lumbar spine disc degeneration disease. European spine journal 17: 492 503.

77. Meisel HJ, Siodla V, Ganey T, Minkus Y, Hutton WC, et al. (2007) Clinical experience in cell-based therapeutics: disc chondrocyte transplantation a treatment for degenerated or damaged intervertebral disc. Biomol Eng 24 5-21.

78. Nomura T, Mochida J, Okuma M, Nishimura K, Sakabe K (2001) Nucleus pulposus allograft retards intervertebral disc degeneration. Clin Orthop Relat Res: 94-101.
79. Carragee EJ, Don AS, Hurwitz EL, Cuellar JM, Carrino JA, et al. (2009) 2009 ISSLS Prize Winner: Does discography cause accelerated progression of degeneration changes in the lumbar disc: a ten-year matched cohort study. Spine (Phila Pa 1976) 34: 2338-2345.

80. Michalek AJ, Buckley MR, Bonassar LJ, Cohen I, latridis JC (2010) The effects of needle puncture injury on microscale shear strain in the intervertebral disc annulus fibrosus. Spine J 10: 1098-1105.

81. Nassr A, Lee JY, Bashir RS, Rihn JA, Eck JC, et al. (2009) Does incorrect level needle localization during anterior cervical discectomy and fusion lead to accelerated disc degeneration? Spine (Phila Pa 1976) 34: 189-192.

82. Bergknut N, Rutges JP, Kranenburg HJ, Smolders LA, Hagman R, et al (2012) The dog as an animal model for intervertebral disc degeneration? Spine (Phila Pa 1976) 37: 351-358.

83. de Vries S, Potier E, Doeselaar Mv, Meij B, Tryfonidou M and Ito K (2014) Conditioned medium derived from notochordal cell-rich nucleus pulposus tissue stimulates matrix production by canine nucleus pulposus cells and bone marrow derived stromal cells. Tissue Eng Part A 21:1077-84.

84. Potier E, de Vries S, van Doeselaar M, Ito K (2014) Potential application of notochordal cells for intervertebral disc regeneration: an in vitro assessment. Eur Cell Mater 28: 68-80.

85. Risbud MV, Schaer TP, Shapiro IM (2010) Toward an understanding of the role of notochordal cells in the adult intervertebral disc: from discord to accord. Dev Dyn 239: 2141-2148.

86. Kim KW, Lim TH, Kim JG, Jeong ST, Masuda K, et al. (2003) The origin of chondrocytes in the nucleus pulposus and histologic findings associated with the transition of a notochordal nucleus pulposus to a fibrocartilaginous nucleus pulposus in intact rabbit intervertebral discs. Spine (Phila Pa 1976) 28: 982-990.

87. Sakaguchi Y, Sekiya I, Yagishita K, Muneta T (2005) Comparison of human stem cells derived from various mesenchymal tissues: superiority of synovium as a cell source. Arthritis Rheum 52: 2521-2529.

88. Jiang $\mathrm{Y}$, Jahagirdar BN, Reinhardt RL, Schwartz RE, Keene CD, et al. (2002) Pluripotency of mesenchymal stem cells derived from adult marrow. Nature 418: 41-49.

89. Kemp KC, Hows J, Donaldson C (2005) Bone marrow-derived mesenchymal stem cells. Leuk Lymphoma 46: 1531-1544.

90. De Bari C, Dell'Accio F, Tylzanowski P, Luyten FP (2001) Multipotent mesenchymal stem cells from adult human synovial membrane. Arthritis Rheum 44: 1928-1942.

91. De Bari C, Dell'Accio F, Vanlauwe J, Eyckmans J, Khan IM, et al. (2006) Mesenchymal multipotency of adult human periosteal cells demonstrated by single-cell lineage analysis. Arthritis Rheum 54: 1209-1221.

92. Yoshimura H, Muneta T, Nimura A, Yokoyama A, Koga $\mathrm{H}$, et al. (2007) Comparison of rat mesenchymal stem cells derived from bone marrow, synovium, periosteum, adipose tissue, and muscle. Cell Tissue Res 327 : 449-462.

93. Clarke LE, McConnell JC, Sherratt MJ, Derby B, Richardson SM, et al. (2014) Growth differentiation factor 6 and transforming growth factor-beta differentially mediate mesenchymal stem cell differentiation, composition, and micromechanical properties of nucleus pulposus constructs. Arthritis Res Ther 16: 67.

94. Richardson SM, Hughes N, Hunt JA, Freemont AJ, Hoyland JA (2008) Human mesenchymal stem cell differentiation to NP-like cells in chitosan-glycerophosphate hydrogels. Biomaterials 29: 85-93.

95. Tao F, Li F, Li G, Pan F (2008) Differentiation of mesenchymal stem cells into nucleus pulposus cells in vitro. J Huazhong Univ Sci Technolog Med Sci 28: 156-158.

96. Orozco L, Soler R, Morera C, Alberca M, Sánchez A, et al. (2011) Intervertebral disc repair by autologous mesenchymal bone marrow cells: a pilot study. Transplantation 92: 822-828. 
97. Zhang YG, Guo X, Xu P, Kang LL, Li J (2005) Bone mesenchymal stem cells transplanted into rabbit intervertebral discs can increase proteoglycans. Clin Orthop Relat Res: 219-226.

98. Strassburg S, Hodson NW, Hill PI, Richardson SM, Hoyland JA (2012) Bi-directional exchange of membrane components occurs during co-culture of mesenchymal stem cells and nucleus pulposus cells. PLoS One 7: 33739

99. Strassburg S, Richardson SM, Freemont AJ, Hoyland JA (2010) Co-culture induces mesenchymal stem cell differentiation and modulation of the degenerate human nucleus pulposus cell phenotype. Regen Med 5: 701-711.

100. Naqvi SM, Buckley CT (2015) Differential response of encapsulated nucleus pulposus and bone marrow stem cells in isolation and coculture in alginate and chitosan hydrogels. Tissue Eng Part A 21: 288-299.

101. Wei A, Tao H, Chung SA, Brisby H, Ma DD, et al. (2009) The fate of transplanted xenogeneic bone marrow-derived stem cells in rat intervertebral discs. J Orthop Res 27: 374-379.

102. Le Maitre CL, Baird P, Freemont AJ, Hoyland JA (2009) An in vitro study investigating the survival and phenotype of mesenchymal stem cells following injection into nucleus pulposus tissue. Arthritis Res Ther 11: 20

103. Henriksson HB, Svanvik T, Jonsson M, Hagman M, Horn M, et al (2009) Transplantation of human mesenchymal stems cells into intervertebral discs in a xenogeneic porcine model. Spine (Phila Pa 1976) 34: 141-148.

104. Acosta FL Jr, Metz L, Adkisson HD, Liu J, Carruthers-Liebenberg E, et al. (2011) Porcine intervertebral disc repair using allogeneic juvenile articular chondrocytes or mesenchymal stem cells. Tissue Eng Part A 17: 30453055 .

105. Vadalà G, Sowa G, Hubert M, Gilbertson LG, Denaro V, et al. (2012) Mesenchymal stem cells injection in degenerated intervertebral disc: cell leakage may induce osteophyte formation. J Tissue Eng Regen Med 6: 348-355

106. Richardson SM, Walker RV, Parker S, Rhodes NP, Hunt JA, et al. (2006) Intervertebral disc cell-mediated mesenchymal stem cell differentiation. Stem Cells 24: 707-716.

107. Roughley P, Hoemann C, DesRosiers E, Mwale F, Antoniou J, et al. (2006) The potential of chitosan-based gels containing intervertebral disc cells for nucleus pulposus supplementation. Biomaterials 27: 388-396

108. Minogue BM, Richardson SM, Zeef LA, Freemont AJ, Hoyland JA (2010) Transcriptional profiling of bovine intervertebral disc cells: implications for identification of normal and degenerate human intervertebral disc cell phenotypes. Arthritis Res Ther 12: 22.

109. Benzel EC, Lieberman IH, Ross ER, Linovitz RJ, Kuras J, Zimmers K (2011) Mechanical characterization of a viscoelastic disc for lumbar total disc replacement. Journal of Medical Devices 5: 011005.

110. Joung YK, Bae JW, Park KD (2008) Controlled release of heparin-binding growth factors using heparin-containing particulate systems for tissue regeneration. Expert Opin Drug Deliv 5: 1173-1184.

111. Nie H, Wang $\mathrm{CH}$ (2007) Fabrication and characterization of PLGA/HAp composite scaffolds for delivery of BMP-2 plasmid DNA. J Control Release 120: 111-121.

112. Park H, Temenoff JS, Tabata Y, Caplan AI, Mikos AG (2007) Injectable biodegradable hydrogel composites for rabbit marrow mesenchymal stem cell and growth factor delivery for cartilage tissue engineering. Biomaterials 28: $3217-3227$

113. Hughes SP, Freemont AJ, Hukins DW, McGregor AH, Roberts S (2012) The pathogenesis of degeneration of the intervertebral disc and emerging therapies in the management of back pain. J Bone Joint Surg Br 94: 12981304

114. Jacobs W, Van der Gaag NA, Tuschel A, de Kleuver M, Peul W, et al. (2012) Total disc replacement for chronic back pain in the presence of disc degeneration. Cochrane Database Syst Rev 9: CD008326.
115. Siepe CJ, Heider F, Wiechert K, Hitzl W, Ishak B, et al. (2014) Mid- to longterm results of total lumbar disc replacement: a prospective analysis with 5- to 10-year follow-up. Spine J 14: 1417-1431.

116. Mahomed A, Moghadas PM, Shepherd DE, Hukins DW, Roome A, et al (2012) Effect of axial load on the flexural properties of an elastomeric total disc replacement. Spine (Phila Pa 1976) 37: 908-912.

117. Gebhard H, Bowles R, Dyke J, Saleh T, Doty S, et al. (2010) Total disc replacement using a tissue-engineered intervertebral disc in vivo: new animal model and initial results. Evid Based Spine Care J 1: 62-66.

118. Bowles RD, Gebhard HH, Dyke JP, Ballon DJ, Tomasino A, et al. (2012) Image-based tissue engineering of a total intervertebral disc implant for restoration of function to the rat lumbar spine. NMR Biomed 25: 443-451.

119. Séguin CA, Grynpas MD, Pilliar RM, Waldman SD, Kandel RA (2004) Tissue engineered nucleus pulposus tissue formed on a porous calcium polyphosphate substrate. Spine (Phila Pa 1976) 29: 1299-1306.

120. Waldman SD, Grynpas MD, Pilliar RM, Kandel RA (2002) Characterization of cartilagenous tissue formed on calcium polyphosphate substrates in vitro. J Biomed Mater Res 62: 323-330.

121. Sakai D, Mochida J, Yamamoto Y, Nomura T, Okuma M, et al. (2003) Transplantation of mesenchymal stem cells embedded in Atelocollagen gel to the intervertebral disc: a potential therapeutic model for disc degeneration. Biomaterials 24: 3531-3541.

122. Slaughter BV, Khurshid SS, Fisher OZ, Khademhosseini A, Peppas NA (2009) Hydrogels in regenerative medicine. Adv Mater 21: 3307-3329.

123. Klouda L, Mikos AG (2008) Thermoresponsive hydrogels in biomedical applications. Eur J Pharm Biopharm 68: 34-45.

124. Chen J, Cheng T (2009) Preparation and evaluation of thermo-reversible copolymer hydrogels containing chitosan and hyaluronic acid as injectable cell carriers. Polymer 50: 107-116.

125. Nesti LJ, Li WJ, Shanti RM, Jiang YJ, Jackson W, et al. (2008) Intervertebral disc tissue engineering using a novel Hyaluronic Acid-Nanofibrous Scaffold (HANFS) amalgam. Tissue Eng Part A 14: 1527-1537.

126. Nerurkar NL, Mauck RL, Elliott DM (2008) ISSLS prize winner: integrating theoretical and experimental methods for functional tissue engineering of the annulus fibrosus. Spine (Phila Pa 1976) 33: 2691-2701.

127. Koepsell L, Zhang L, Neufeld D, Fong H, Deng Y (2011) Electrospun nanofibrous polycaprolactone scaffolds for tissue engineering of annulus fibrosus. Macromol Biosci 11: 391-399.

128. Lazebnik M, Singh M, Glatt P, Friis LA, Berkland CJ, et al. (2011) Biomimetic method for combining the nucleus pulposus and annulus fibrosus for intervertebral disc tissue engineering. J Tissue Eng Regen Med 5: 179-187.

129. Vadalà G, Mozetic $P$, Rainer A, Centola M, Loppini M, et al. (2012) Bioactive electrospun scaffold for annulus fibrosus repair and regeneration. Eur Spine J 1: 20-26.

130. Qiu W, Huang Y, Teng W, Cohn CM, Cappello J, et al. (2010) Complete recombinant silk-elastinlike protein-based tissue scaffold. Biomacromolecules 11: 3219-3227.

131. Reitmaier S, Kreja L, Gruchenberg K, Kanter B, Silva-Correia J, et al (2014) In vivo biofunctional evaluation of hydrogels for disc regeneration. Eur Spine J 23: 19-26.

132. Brayda-Bruno M, Tibiletti M, Ito K, Fairbank J, Galbusera F, et al. (2014) Advances in the diagnosis of degenerated lumbar discs and their possible clinical application. Eur Spine J 3: 315-323. 